\title{
CONSUMERS' KNOWLEDGE, PERCEPTION, AND ATTITUDE TOWARDS NUTRITION AND HEALTH CLAIMS ON DAIRY PRODUCTS AND PURCHASE INTENTION IN JOHOR BAHRU
}

\author{
YAP HUI YEE AND SITI NUR'AFIFAH JAAFAR* \\ School of Food Science and Technology, Universiti Malaysia Terengganu, 21030 Kuala Nerus, Terengganu, \\ Malaysia
}

*Corresponding author: afifah@umt.edu.my

\begin{abstract}
Nowadays the increasing prevalence of dietary disease has raised consumers' awareness of healthy diet and lifestyle. The rise in the use of nutrition and health claims to promote health benefits in food products help consumers make effective food choices. There is very limited research regarding nutrition and health claims in Malaysia. This research focused on consumers' knowledge, perception (i.e. perceived quality, perceived healthiness, perceived value, perceived importance, trust and perceived familiarity), and attitude towards nutrition and health claims on dairy products as well as their purchase intention towards the products, and examine the relationship between these variables in Johor Bahru, Johor. All responses were collected by distributing questionnaire to convenience and quota sample $(n=200)$. Data was analysed to obtain descriptive statistics and correlation analysis. The results showed that most of the consumers $(46 \%)$ had moderate knowledge of nutrition and health claims on dairy products. Consumers generally had almost positive perception and attitude towards nutrition and health claims on dairy products and positive purchase intention towards dairy products. Almost all independent variables correlated with purchase intention towards dairy products. Consumer attitude had the strongest positive relationship with purchase intention $(\mathrm{r}=0.722)$, followed by moderate positive correlation between consumer perception and purchase intention ( $\mathrm{r}=0.671)$, while consumer knowledge only had low relationship with purchase intention $(\mathrm{r}=0.299)$. This study added new knowledge regarding public purchasing behaviour towards dairy products with nutrition and health claims. This research also provided valuable information for both food manufacturers and companies to help them make effective decisions to improve the presentation of nutrition and health claims for better expression of information as well as the goodness of food products in order to attract the attention of health-conscious consumers.
\end{abstract}

Keywords: Consumers' Knowledge, Consumers' Perception, Consumers' Attitude, Consumers' Purchase Intention, Nutrition and Health Claims, Dairy Products

\section{Introduction}

Nowadays, nutrition and health claims have become attractive cues for consumers as the increasing risk of dietary disease has raised consumers' awareness of healthy diet and lifestyle (Lalor et al., 2011a). Consumers are growing an interest in the quality and nutritional content of food products (Ishada et al., 2003; Prescott et al., 2002). Health claims are used as front-ofpackage information which relate food items with specific health-related functions or health outcomes, whereas nutrition claims express the nutrient content in products (Lähteenmäki, 2013). These claims could help consumers make effective food choices and become an excellent marketing strategy as well as increase specific food item intake (Pravst, 2011). However, according to Nielsen (2012), half (59\%) of the global consumers had a hard time understanding the nutritional facts on food packaging. Besides, $80 \%$ of them were also largely sceptical about the accuracy of these claims (Nielsen, 2012). The problem of misleading and false claims on food products has existed and this could reduce consumers' trust regarding the claims.
There is very limited research regarding nutrition and health claims in Malaysia, with research carried out only on perception and purchasing behaviour towards claims (Abdul Latiff et al., 2016; Zafar et al., 2016). Since consumer demands towards milk and dairy products have increased, and the claims are more often shown on dairy products (Babolian Hendijani \& Abdul Karim, 2010), knowledge, perception (i.e. perceived quality, perceived healthiness, perceived value, perceived importance, trust and perceived familiarity), attitude towards nutrition and health claims on dairy products and purchase intention towards dairy products as well as relationship between these variables were studied. Johor Bahru was chosen as the sampling location because it is a developing and highly populated city. The increased number of shopping complexes and hypermarkets in Johor Bahru made it suitable for the present study (Wong \& Benjamin, 2016). This study added new knowledge regarding public purchasing behaviour towards nutrition and health claims on dairy products. Furthermore, this research provided valuable information for both food manufacturers and companies to help them make effective decisions to improve the presentation of nutrition and health claims for better expression of information as well as the goodness of food 
products in order to attract the attention of healthconscious consumers.

This study used Ajzen's Theory of Planned Behaviour (TPB) as base theory (Ajzen, 1991). This theory used attitudes, subjective norms and perceived behavioural control to explain an individual's intention to carry out the behaviour. By using TPB, consumers' attitude and other variables (knowledge and perception) were considered as critical factors to explain the purchase intention of dairy products with nutrition and health claims. In TPB, the more favourable the attitude and toward a behaviour, the more the individual's intention to implement the behaviour under consideration (Ajzen, 1991). Peng et al. (2006) and Sheppard et al. (1998) also indicated that consumers' positive attitude towards the product category increased the intention of future purchase.

Hwang et al. (2016) reported that consumers' overall perceptions $(\mathrm{r}=0.406 ; \mathrm{p}<0.01)$ and healthiness perceptions $(r=0.280 ; p<0.01)$

were significantly and positively correlated to their purchase intentions. Moreover, respondents familiar with product category found the claims on products more convincing and also had a higher intention to purchase them (Verbeke et al., 2009). Bower et al. (2003) and Lalor et al. (2011b) revealed that nutrition knowledge appeared to have slight interactive effects or no correlation on purchase intention of product with claims. However, Morgan (2008) found that consumer nutrition knowledge was significantly associated with purchase intention of breakfast cereal with claims $(p<0.001)$.

\section{Materials and Methods}

Four hypermarkets in Johor Bahru, Malaysia, were selected as sampling location. Convenience sampling and quota sampling were used to sample subjects and location. 50 respondents were approached in each hypermarket $(n=200)$. Convenience sampling is easy, fast, inexpensive, and the respondents are readily available (Wegner, 2010). Quota sampling is a nonprobability sampling method where the total sample will consist of the same distribution of characteristics in the studied population (Babbie, 2016). Figure 1 shows the sampling framework of this research.

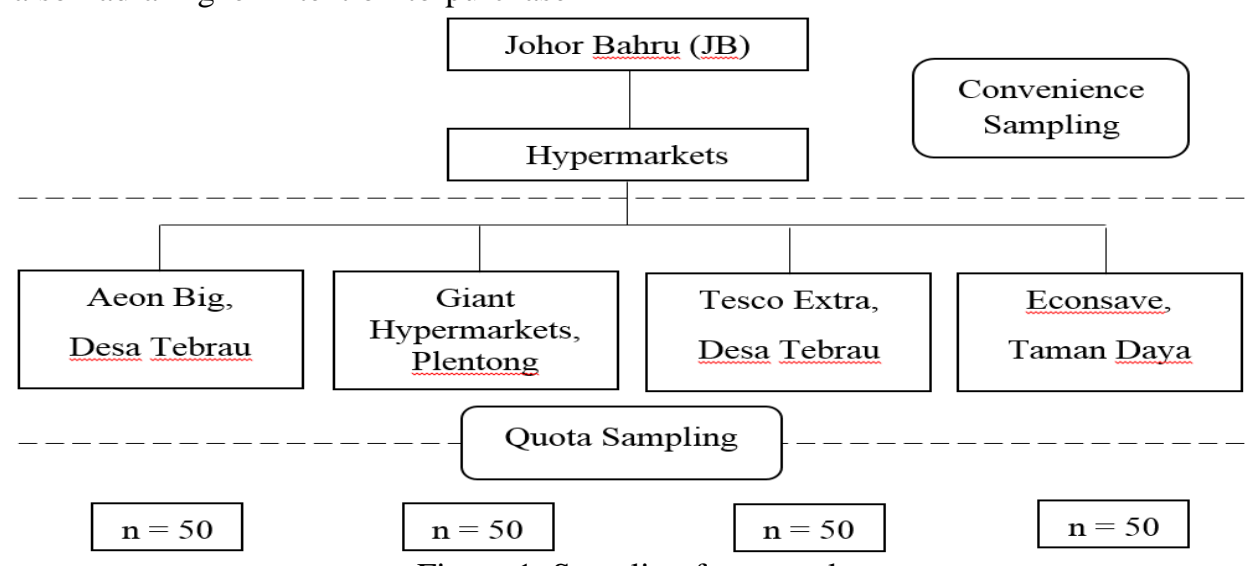

Figure 1: Sampling framework

Total respondent $(n)=200$ from selected hypermarkets

The target respondents were consumers 18 years old and above. A self-administered questionnaire was distributed and the respondents were left to answer the questionnaire (Bryman, 2008). The questionnaire was divided into six sections and used the nominal scale and 5-point Likert scale. Questions regarding the respondents' demographic profile were included in section A. The questions were modified from Jaafar et al. (2012). Section B aimed to determine respondents' consumption of dairy products and the questions were partially adapted from Babolian Hendijani \& Abdul Karim (2010). Section C determined respondents' knowledge towards nutrition and health claims on dairy products and the questions were modified from Mitic \& Gligorijević (2015), MOH (2010) as well as FAO/WHO (2007). Section D, E, and F required respondents to rate their perception and attitude towards nutrition and health claims on dairy products, and their purchase intention towards dairy products respectively. These questions were partially adapted from Vanasse (2016), Lähteenmäki (2013), Wills et al. (2012), Jaafar et al. (2012), Tudoran et al. (2009), and Kozup et al. (2003).

All data were analysed using Statistical Package for Social Sciences (SPSS) version 20.0. The pilot test was conducted to test the reliability and validity of the questionnaire. Some modifications were made to the questionnaire based on the outcome of the pilot test. The main data were analysed to obtain descriptive statistics and inferential statistics. Central Limit Theorem states that the sampling distribution of the sample means will be approximately normal if the sample size is larger than 
30 (Sullivan, 2017). Since the sample size of this study was sufficiently large $(\mathrm{n}=200)$, parametric test was used in this analysis.

Descriptive statistic is concerned with the collection, organization, enumeration of the frequency of characteristics, summarization, and presentation of data. Respondents' demographic profiles, dairy product consumption, knowledge, perception, attitude and purchase intention were also tabulated using frequency and percentage. The inferential statistic was used to compare groups or difference between groups by using analyses of t-test and ANOVA. Other than that, the relationship between consumers' knowledge, perception, attitude, and purchase intention was determined by using the Pearson correlation. The strength of the relationship was referred to the Guilford Rule of Thumb as shown in table 1 below.

Table 1: Guilford Rule of Thumb

\begin{tabular}{ll}
\hline $\mathbf{R}$ & Strength of Relationship \\
\hline$<\mathbf{0 . 2 0}$ & Negligible of relationship \\
$\mathbf{0 . 2 1}-\mathbf{0 . 4 0}$ & Low relationship \\
$\mathbf{0 . 4 1}-\mathbf{0 . 7 0}$ & Moderate relationship \\
$\mathbf{0 . 7 1}-\mathbf{0 . 9 0}$ & High relationship \\
$>\mathbf{0 . 9 0}$ & Very high relationship \\
\hline
\end{tabular}

Source: Sekaran and Bougie (2009)

\section{Results and Discussion \\ Demographic Data}

A total of 200 respondents participated in this research. Table 2 shows the demographic profile of the respondents involved in the present survey 
CONSUMERS' KNOWLEDGE, PERCEPTION AND ATTITUDE TOWARDS NUTRITION AND HEALTH CLAIMS ON DAIRY PRODUCTS AND PURCHASE INTENTION IN JOHOR BAHRU

Table 2: Demographic characteristics of respondents

\begin{tabular}{|c|c|c|}
\hline Demographic factors & Frequency $(n=200)$ & Percentage (\%) \\
\hline \multicolumn{3}{|l|}{ Gender } \\
\hline Male & 68 & 34.0 \\
\hline Female & 132 & 66.0 \\
\hline \multicolumn{3}{|l|}{ Races } \\
\hline Malay & 86 & 43.0 \\
\hline Chinese & 102 & 51.0 \\
\hline Indian & 10 & 5.0 \\
\hline Other & 2 & 1.0 \\
\hline \multicolumn{3}{|l|}{ Age } \\
\hline $18-25$ years old & 72 & 36.0 \\
\hline 26-35 years old & 47 & 23.5 \\
\hline $36-45$ years old & 41 & 20.5 \\
\hline $46-55$ years old & 23 & 11.5 \\
\hline Above 56 years old & 17 & 8.5 \\
\hline \multicolumn{3}{|l|}{ Educational Level } \\
\hline Primary & 9 & 4.5 \\
\hline Secondary & 55 & 27.5 \\
\hline STPM/ Diploma & 62 & 31.0 \\
\hline Bachelor's degree & 68 & 34.0 \\
\hline Master's degree & 2 & 1.0 \\
\hline $\mathrm{PhD}$ & 1 & 0.5 \\
\hline Other & 3 & 1.5 \\
\hline \multicolumn{3}{|l|}{ Employment Status } \\
\hline Employed (Full time/ Part time) & 137 & 68.5 \\
\hline Self-employed & 14 & 7.0 \\
\hline Unemployed & 23 & 11.5 \\
\hline Students & 26 & 13.0 \\
\hline \multicolumn{3}{|l|}{ Monthly Household Income } \\
\hline Less than RM 1,499 & 32 & 16.0 \\
\hline RM $1,500-$ RM 2,999 & 54 & 27.0 \\
\hline RM 3,000 - RM 3,999 & 26 & 13.0 \\
\hline RM 4,000 - RM 4,999 & 18 & 9.0 \\
\hline RM 5,000 - RM 5,999 & 26 & 13.0 \\
\hline More than RM 6,000 & 44 & 22.0 \\
\hline
\end{tabular}

Table 2 shows that majority of respondents were female and between $18-25$ years old $(36.0 \%)$. The highest education for most respondents was bachelor education $(34.0 \%)$. The majority of respondents earned between RM1, 500-RM2, 999 monthly income (27.0\%) while most respondents were employed $(68.5 \%)$.
Level of Consumer Knowledge towards Nutrition and Health Claims on Dairy Products

A total of 20 questions were prepared and the total score of the answers selected by each consumer was categorized into high, medium and low knowledge. Table 3 shows the level of consumer knowledge towards nutrition and health claims on dairy products. 
Table 3: Level of consumer knowledge towards nutrition and health claims on dairy products

\begin{tabular}{ccc}
\hline $\begin{array}{c}\text { Level of knowledge towards nutrition and health } \\
\text { claims on dairy products }\end{array}$ & Frequency $(\mathbf{n = 2 0 0})$ & Percentage (\%) \\
\hline High & 67 & 33.5 \\
Medium & 92 & 46.0 \\
Low & 41 & 20.5 \\
\hline
\end{tabular}

Note: Consumer knowledge (Scale: Yes=1 marks/ No and Not sure=0 marks) - Sum up total marks for 20 questions with $\min$. score $=0 ;$ max. score $=20$

Knowledge was categorized into 3 levels: high (14-20), medium (7-13) and low (0-6) (Nekesa, 2012)

Based on Table 3, most of the respondents $(46.0 \%)$ possessed moderate knowledge of nutrition and health claims on dairy products, followed by $33.5 \%$ with high knowledge and only $20.5 \%$ respondents had low knowledge. Žeželj et al. (2012) was in agreement with the present results which showed that consumers had moderate level of nutrition knowledge, with $66.5 \%$ of items answered correctly. Mitic and Gligorijević (2015) stated that respondents who demonstrated higher knowledge were those who were better informed about products and therefore considered the claims as more important.

This result contrasted with Mitic and Gligorijević (2015) where they found that consumers expressed low level of knowledge, with only $3 \%$ of the respondents having more than 7 correct answers from a total of 10 questions, $25 \%$ of the respondents answering correctly on less than 5 questions (10\% answered correctly on 2 or 3 questions). Most of the respondents were in the group of those with 5 or 6 correct answers (48\%). Similarly, Lalor et al. (2011a) also reported that consumers generally had low level of nutrition knowledge. Only $46 \%$ of respondents professed to be knowledgeable (Bower et al., 2003).

Besides, the group of respondents with some chronic health problems expressed lower level of nutrition knowledge than those without chronic illness (Mitic \& Gligorijević, 2015). Consumers with high nutrition knowledge were those possessing high level of education. The greater chances of consumers to be exposed to nutrition education could explain their greater nutrition knowledge (Garretson \& Burton, 2000).

\section{Consumer Perception towards Nutrition and Health Claims on Dairy products}

The components of 17 perception attribute questions included perceived quality, perceived healthiness, perceived value, perceived importance, trust as well as familiarity. Table 4 shows the consumer perception towards nutrition and health claims on dairy products.

Table 4: Consumer perception towards nutrition and health claims on dairy products

\begin{tabular}{clcc}
\hline No & \multicolumn{1}{c}{ Items } & Mean & $\begin{array}{c}\text { Standard } \\
\text { deviation }\end{array}$ \\
\hline 1 & $\begin{array}{l}\text { Consumer perceived quality towards nutrition and health claims on dairy } \\
\text { products }\end{array}$ & 3.53 & 0.80 \\
2 & $\begin{array}{l}\text { Consumer perceived healthiness towards nutrition and health claims on } \\
\text { dairy products }\end{array}$ & 3.49 & 0.78 \\
3 & $\begin{array}{l}\text { Consumer perceived value towards nutrition and health claims on dairy } \\
\text { products }\end{array}$ & 3.31 & 0.74 \\
4 & $\begin{array}{l}\text { Consumer perceived importance of nutrition and health claims on dairy } \\
\text { products }\end{array}$ & 3.54 & 0.79 \\
\hline & $\begin{array}{l}\text { Consumer trust of nutrition and health claims on dairy products } \\
\text { Consumer familiarity of nutrition and health claims on dairy products }\end{array}$ & 3.45 & 0.76 \\
\hline
\end{tabular}

Note:

Consumer perception was rated on 5-point Likert scale, from 1= Strongly disagree to 5=Strongly agree.

Table 4 shows that respondents had almost positive perception towards nutrition and health claims on dairy products. According to the mean score, consumer perceived importance, quality, healthiness, and trust of nutrition and health claims on dairy products more positively whereas the mean score of consumer perceived value and familiarity of nutrition and health claims on dairy products were lower. A similar study by Mitić and Gligorijević (2015) showed that consumers perceived importance of nutrition and health claims on 
food products as moderately positive. Higher confidence in the truthfulness of food labels and knowledge led to higher perceived importance of claims (Mitić \& Gligorijević, 2015), indicating that respondents in the present study may have more trust about claims to perceive the importance of claims positively. Another study conducted in America by Sloan (2012) reported that consumers considered the presence of health claims on food labels assured the quality of food.

This result was supported by most studies where presenting health claims could increase perceived healthiness (e.g. Lähteenmäki, 2013; Saba et al., 2010; Dean et al., 2007; Lyly et al., 2007; van Trijp \& van der Lans, 2007; van Kleef et al., 2005; Urala et al., 2003). Consumers needed to possess positive attitudes towards products with health claims in order for them to perceive health claims positively (Dean et al., 2012). This finding was also supported by Morgan (2008) who stated that in general, respondents had moderate level of trust in nutrition content claims. About half of the respondents admitted that they would trust big food companies to provide them with accurate claims (Lalor et al., 2010).
Lalor et al. (2011a) reported that consumers perceived the value and preferred products with claims more than products with no claims. Most of the respondents over 55 years were more inclined to buy a product with health claims if the product was reduced in price (Dean et al., 2012). Besides, lack of nutrition knowledge may limit the ability of consumers to assess claims and hence may decrease their perceived value and familiarity of claims (Svederberg, 2002). Once consumers were familiar with the nutrient and disease relationship, this would help them to evaluate the product with claims.

\section{Consumer Attitude towards Nutrition and Health Claims on Dairy products}

For investigating respondents' attitude towards nutrition and health claims on dairy products, 5 questions were prepared in the questionnaire. Table 5 shows consumer attitude towards nutrition and health claims on dairy products.

Table 5: Consumer attitude towards nutrition and health claims on dairy products

\begin{tabular}{clcc}
\hline No & \multicolumn{1}{c}{ Items } & Mean & $\begin{array}{c}\text { Standard } \\
\text { deviation }\end{array}$ \\
\hline 1 & $\begin{array}{l}\text { Consumers think that nutrition and health claims made on dairy products } \\
\text { are useful. }\end{array}$ & 3.57 & 0.86 \\
2 & $\begin{array}{l}\text { Consumers think that nutrition and health claims made on dairy products } \\
\text { are accurate. }\end{array}$ & 3.26 & 0.84 \\
3 & $\begin{array}{l}\text { Consumers think that nutrition and health claims made on dairy products } \\
\text { are truthful. } \\
\text { Consumers think that nutrition and health claims made on dairy products } \\
\text { are easy to understand. } \\
\text { Consumers think that nutrition and health claims made on dairy products } \\
\text { are highly attractive. }\end{array}$ & 3.25 & 0.81 \\
\hline
\end{tabular}

Note: Consumer attitude was 5-point Likert scale where 1=Strongly disagree to 5=Strongly agree.

The result showed that respondents had almost positive attitude towards nutrition and health claims on dairy products. Mitić and Gligorijević (2015), Kozup et al. (2003) and Trolle and Thorsen (2001) also stated that consumers had a positive attitude about health claims. Žeželj et al. (2012) reported that nutrition knowledge, as well as trust in claims and the usage of labels were identified as the major influences on consumers' attitudes toward health claims.

According to the mean score, consumers think that nutrition and health claims made on dairy products were more useful, highly attractive and were easy to understand, while there was a lower mean score for consumers who think that nutrition and health claims made on dairy products were accurate and truthful. Williams (2005) demonstrated that consumers generally think health claims were helpful in making betterinformed food choices. Vanasse (2016) reported that the presentation of health claims on product packaging could be attractive to health-conscious shoppers.
However, Nielsen (2012) reported that over two-thirds of global consumers never believed nutritional claims as they considered the claims to be mainly an advertising tool and a marketing scam from the food industry (Singer et al., 2006). Mitić and Gligorijević (2015) stated that the negative attitude toward claims may be caused by a high distrust of food labels and low awareness as well as knowledge about those products.

\section{Consumer Purchase Intention towards Dairy products with Nutrition and Health Claims}

There were 4 questions in the questionnaire used to determine respondents' purchase intention towards dairy products with nutrition and health claims. Table 6 shows the consumer purchase intention towards dairy products with nutrition and health claims. 
Table 6: Consumer purchase intention towards dairy products with nutrition and health claims

\begin{tabular}{|c|c|c|c|}
\hline No & Items & Mean & $\begin{array}{l}\text { Standard } \\
\text { deviation }\end{array}$ \\
\hline 1 & $\begin{array}{l}\text { Consumers will buy dairy products with nutrition and health claims for } \\
\text { health benefits. }\end{array}$ & 3.60 & 0.86 \\
\hline 2 & $\begin{array}{l}\text { Consumers will consider to purchase dairy products with nutrition and } \\
\text { health claims. }\end{array}$ & 3.64 & 0.82 \\
\hline 3 & $\begin{array}{l}\text { Consumers will definitely purchase dairy products with nutrition and } \\
\text { health claims in future. }\end{array}$ & 3.53 & 0.77 \\
\hline 4 & $\begin{array}{l}\text { Consumers willing to pay more for dairy products with nutrition and } \\
\text { health claims. }\end{array}$ & 3.30 & 0.87 \\
\hline
\end{tabular}

Based on Table 6, respondents had almost positive purchase intention towards dairy products with nutrition and health claims. This may indicate consumers will consider purchasing dairy products with nutrition and health claims for health benefits. The present finding was in line with van Trijp and van der Lans (2007) and Coleman et al. (2014) who showed that the presence of a health-nutrition claim and health claims increased consumer purchase intention due to consumers' positive reaction towards products with claims. The general health interest and relevance were also considered to increase the purchase intention of products with claims (Dean et al., 2012). As a result, the positive purchase intention may be due to the respondents recognisiing the benefits of products with claims.

The present study showed that consumers rated lower intention to pay more for dairy products with claims. Consumers were willing to pay more for the products with claims with the price lower than the retail price (Bower et al., 2003). Hwang et al. (2016) stated that consumers were probably willing to pay more for products with claims if they perceived their benefits. Generally, older female with high nutritional knowledge and high health concern sub-groups were willing to pay more for added functional benefits on claims (Bower $e t$ al., 2003).

\section{Relationship between Consumer Knowledge, Perception, Attitude and Purchase Intention towards Nutrition and Health Claims on Dairy Products}

The framework used in this study was Theory of Planned Behaviour (TPB) introduced by Ajzen (1991). This theory uses three conceptually independent determinants (attitudes, subjective norms, and perceived behavioural control) to explain an individual's intention to perform the behaviour. Figure 2 illustrates the model of Theory of Planned Behaviour.

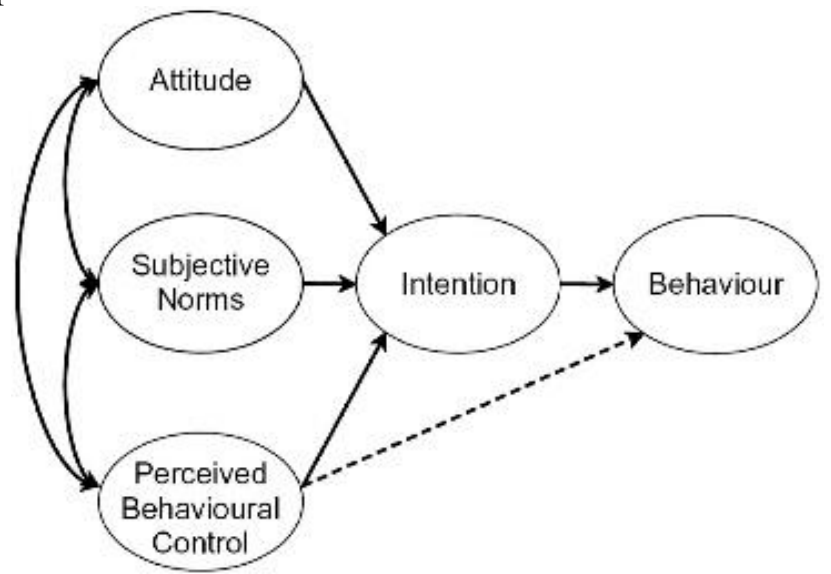

Figure 2: Theory of Planned Behaviour (Ajzen, 1991)

From TPB, individual's intention and behaviour are related to attitude towards performing the behaviour (Ajzen, 1991). By using TPB, consumers' attitude and other variables (knowledge and perception) are considered as critical factors to predict and explain the purchase intention of dairy products with nutrition and health claims. Table 7 shows the correlation between consumer knowledge, perception, and attitude towards nutrition and health claims on dairy products and purchase intention towards the products. 
Table 7: Correlation between consumer knowledge, perception, and attitude towards nutrition and health claims on dairy and purchase intention towards the products

\begin{tabular}{lccc}
\hline Variables & $\begin{array}{c}\text { Knowledge towards } \\
\text { nutrition and health } \\
\text { claims on dairy } \\
\text { products }\end{array}$ & $\begin{array}{c}\text { Perception towards } \\
\text { nutrition and health } \\
\text { claims on dairy } \\
\text { products }\end{array}$ & $\begin{array}{c}\text { Attitude towards } \\
\text { nutrition and health } \\
\text { claims on dairy } \\
\text { products }\end{array}$ \\
\hline $\begin{array}{l}\text { Purchase intention towards } \\
\text { dairy products }\end{array}$ & $0.299^{* *}$ & $0.671^{* *}$ & $0.722^{* *}$ \\
\hline
\end{tabular}

Pearson correlation test was used.

**Correlation is significant at the 0.01 level (2-tailed)

As shown in Table 7, consumer attitude had the strongest positive relationship with purchase intention, followed by moderate positive correlation between consumer perception and purchase intention, while consumer knowledge only had a low relationship with purchase intention towards dairy products. Consumer knowledge on claims only had a significant low positive relationship with purchase intention towards dairy products $(\mathrm{r}=0.299, \mathrm{p}<0.001)$. This finding indicated that consumer knowledge was not one of the critical factors which could influence their purchase intention on products with nutrition and health claims. The result was in line with Bower et al. (2003) who concluded that nutrition knowledge appeared to have slight interactive effects on purchase intention towards products with claims. Furthermore, no correlation between selfreported nutrition knowledge and purchase intention was observed in the findings by Lalor et al. (2011b).

Understanding of claims needed some prior knowledge (Mitić \& Gligorijević, 2015). Although consumers who had knowledge regarding claims were able to recognise the health benefits of products with health claims, they might not necessarily be willing to purchase the products since there still existed other barriers such as price, refusal to change, taste and preference (Lappalainen et al., 1998). Therefore, the research was in agreement with the present finding which showed that subjective knowledge of respondents did not necessarily increase the purchase intention of products with nutrition and health claims.

However, Morgan (2008) found that consumer nutrition knowledge was significantly associated with purchase intention of breakfast cereal with claims $(p<0.001)$, with respondents who had low nutrition knowledge having higher purchase intention. This may be caused by the fact that bad health status was more often found in respondents with low education and nutrition knowledge, thus they might be interested in the beneficial effects claimed by the products (Mitic \& Gligorijević, 2015). This result contrasted with Baglione et al. (2012) and Verbeke et al. (2009) who reported higher purchase intention in those knowledgeable about the nutrient claims on food packaging. The discrepancy of the results may be due to the fact that the nutrients and claims chosen for their study were less common, and of a further technical nature, which contributed bigger potential to differentiate among respondents on this basis (Coleman et al., 2014).

The result showed that significant moderate positive correlation existed between consumer perception and purchase intention on dairy products with nutrition and health claims $(\mathrm{r}=0.671, \mathrm{p}<0.001)$. Hwang et al. (2016) was in line with present finding, reporting that if consumers had more positive perceptions toward the product with claims, then they were more likely to purchase the product. Hwang et al. (2016) proved that consumers' overall perceptions $(r=0.406 ; \mathrm{p}<0.01)$ and healthiness perceptions $(\mathrm{r}=0.280 ; \mathrm{p}<0.01)$ were significantly and positively correlated with their purchase intentions. Consumers who perceived the products with claims highly contributed to higher hedonic expectations towards the beneficial effects claimed by the products, which could further explain their high purchase intention towards products with claims (Tudoran et al., 2009).

Morgan (2008) stated that respondents who had high trust in claims would have higher breakfast cereal purchase intention than respondents with medium and low trust in claims $(\mathrm{p}<0.001)$. Perception of the credibility of claims also significantly increased consumers' purchase intention, however to a lower level (Williams et al., 2008). Besides, respondents who were familiar with the product category found the claims more credible and had higher intention to purchase them in the future (Verbeke et al., 2009). Therefore, Saba et al. (2010) reported that Italians not having familiarity with health claims may explain their negative purchase intention towards products with health claims. Consumers' intentions to purchase the products with claims were lower for those who perceived the claims as a marketing scam (Verbeke et al., 2009).

Moreover, consumer attitude towards nutrition and health claims on dairy products had a significant high positive relationship with purchase intention towards dairy products with nutrition and health claims $(r=0.722$, $\mathrm{p}<0.001$ ). It can be concluded that the positive attitude of consumers towards nutrition and health claims on dairy 
products would contribute to higher purchase intention of products with claims. This finding was supported by Peng et al. (2006) who proved that consumers' positive attitude and familiarity with the product category increased the intention of future purchase. This claim was also supported by Sheppard et al. (1998) who stated that attitudes were highly correlated with intention and afterward behaviour. In TPB, the more favourable the attitude and toward a behaviour, the more the individual's intention to implement the behaviour under consideration (Ajzen, 1991).

\section{Conclusion}

This study revealed that most of the consumers (46\%) had moderate knowledge level towards nutrition and health claims on dairy products. Consumers generally had almost positive perception and attitude towards nutrition and health claims on dairy products and positive purchase intention towards these dairy products. In examining the relationship between consumer knowledge, perception and attitude towards nutrition and

\section{References}

Ajzen, I. (1991). The theory of planned behaviour. Organizational Behaviour and Human Decision Processes, 50(2), 179-211.

Babbie, E. R. (2016). The basics of social research. United States, US: Cengage Learning, 195-197.

Babolian Hendijani, R., \& Abdul Karim, M. S. (2010). Factors affecting milk consumption among school children in urban and rural areas of Selangor, Malaysia. International Food Research Journal, 17, 651-660.

Baglione, S. L., Tucci, L. A., \& Stanton, J. L. (2012). Self-reported nutritional knowledge and the acceptance of health-related food benefit claims. Brit Food J, 114(4), 453-468.

Bower, J. A., Saadat, M. A., \& Whitten, C. (2003). Effect of liking, information and consumer characteristics on purchase intention and willingness to pay more for a fat spread with a proven health benefit. Food Quality and Preference, 14(1), 65-74.

Coleman, K. L., Miah, E. M., Morris, G. A., \& Morris, C. (2014). Impact of health claims in prebioticenriched breads on purchase intent, emotional response and product liking. International journal of food sciences and nutrition, 65(2), 164-171.

Dean, M., Shepherd, R., Arvola, A., Vassallo, M., Winkelmann, M., \& Claupein, E. (2007). Consumer perceptions of healthy cereal products and production methods. Journal of Cereal Science, 46(3), 188-196. health claims on dairy products and purchase intention towards these dairy products, the result reported that consumer attitude had the strongest positive relationship with purchase intention $(\mathrm{r}=0.722)$, followed by moderate positive correlation between consumer perception and purchase intention( $\mathrm{r}=0.671)$, while consumer knowledge only had a low relationship with purchase intention $(\mathrm{r}=0.299)$. This study adds new knowledge regarding public purchasing behaviour towards dairy products with nutrition and health claims. Furthermore, this research provides valuable information for both food manufacturers and companies to make effective decisions to improve the presentation of nutrition and health claims for better expression of information as well as the quality of food products in order to attract the attention of health-conscious consumers.

\section{Acknowledgements}

The authors would like to thank hypermarket managers for the permission to approach customers and collect the data to complete this project.

Dean, M., Lampila, P., Shepherd, R., Arvola, A., Saba, A., Vassallo, M., \& Lähteenmäki, L. (2012). Perceived relevance and foods with health-related claims. Food Quality and Preference, 24(1), 129135.

Food and Agriculture Organization/World Health Organization (FAO/WHO). (2007). Guidelines for use of nutrition and health claims. In: Codex Alimentarius Food Labelling. Retrived from http://www.fao.org/input/download/standards/351/C XG_023e.pdf, 10 May 2017.

Garretson, J., \& Burton, S. (2000). Effects of nutrition facts panel values, nutrition claims, and health claims on consumer attitudes, perceptions of disease-related risks, and trust. J Pub Pol Marketing, 19(2), 213-227.

Hwang, J., Lee, K., \& Lin, T. N. (2016). Ingredient labeling and health claims influencing consumer perceptions, purchase intentions, and willingness to pay. Journal of Foodservice Business Research, 19(4), 352-367.

Ishida, A., Law, S. H., \& Aita, Y. (2003). Changes in food consumption expenditure in Malaysia. Agribusiness, 19(1), 61-76.

Jaafar, S. N., Lalp, P. E., \& Naba, M. M. (2012). Consumers' perceptions, attitudes and purchase intention towards private label food products in Malaysia. Asian Journal of Business and Management Sciences, 2(8), 73-90. 
Kozup, J., Creyer, E., \& Burton, S. (2003). Making Healthful Food Choices: The Influence of Health Claims and Nutrition Information on Consumers' Evaluations of Packaged Food Products and Restaurant Menu Items. Journal of Marketing, 67(2), 19-34.

Lähteenmäki, L. (2013). Claiming health in food products. Food Quality and Preference, 27(2), 196201.

Lalor, F., Kennedy, J., Flynn, M. T., \& Wall, P. G. (2010). A study of nutrition and health claims - a snapshot of what's on the Irish market. Public Health Nutrition, 13(5), 704-711.

Lalor, F., Madden, C., McKenzie, K., \& Wall, P. G. (2011a). Health claims on foodstuffs: A focus group study of consumer attitudes. Journal of Functional Foods, 3(1), 56-59.

Lalor, F., Kennedy, J., \& Wall, P. G. (2011b). Impact of nutrition knowledge on behaviour towards health claims on foodstuffs. Brit Food J, 113(6), 753-765.

Lappalainen, R., Kearney, J., \& Gibney, M. (1998). A pan EU survey of consumer attitudes to food, nutrition and health: An overview. Food Quality and Preference, 9(6), 467-478.

Lyly, M., Roininen, K., Honkapää, K., Poutanen, K., \& Lähteenmäki, L. (2007). Factors influencing consumers' willingness to use beverages and readyto-eat frozen soups containing oat b-glucan in Finland, France and Sweden. Food Quality and Preference, 18(2), 242-255.

Ministry of Health Malaysia (MOH). (2010). Guide to Nutrition Labelling and Claims. Retrieved from https://extranet.who.int/nutrition/gina/sites/default/fi le s/MYS\%202010\% 20Guide\%20to\%20Nutrition\%20Labelling\%20and \%20Claims.pdf, 15 April 2017.

Morgan, R. (2008). An investigation into the impact of Nutrition Content claims on packaging in relation to consumer purchase intention, nutrition attitude and health benefits. Food Standards Australia New Zealand. $182 \mathrm{p}$.

Mitić, S., \& Gligorijević, M. (2012). Consumers' attitudes towards nutrition labeling and health claims on food products in Serbia. $3^{\text {rd }}$ EMAC CEE Regional Conference, September 12-14. Belgrade, Faculty of Economics, University of Belgrade. 83-89.
Mitić, S., \& Gligorijević, M. (2015). Consumers' Attitudes, Knowledge and Consumption of Products with Nutrition and Health Claims. Economics of Agriculture, 62(2), 335-352.

Nekesa, M. (2012). Nutritional knowledge, attitudes and practices of primary caregivers of home grown school feeding programme pupils at Sauri Millenium village. School of Public health of Kenyatta University, 41p.

Nielsen. (2012). A Nielsen Report: Battle of the Bulge and Nutrition Labels, healthy eating and trend around the world. Retrieved from http://silvergroup.asia/wpcontent/uploads /2012/02/Nielsen-Global-FoodLabeling-Report-Jan 2012.pdf, 5 May 2017.

Peng, Y., West, G. E., \& Wang, C. (2006). Consumer Attitudes and Acceptance of CLA-Enriched Dairy Products. Canadian Journal of Agricultural Economics/Revue canadienne d'agroeconomie, 54(4), 663-684.

Pravst, I. (2011). Risking public health by approving some health claims? - The case of phosphorus. Food Policy, 36(5), 726-728.

Prescott, J., Young, O., O'Neill, L., Yau, N. J. N., \& Stevens, R. (2002). Motives for food choice: a comparison of consumers from Japan, Taiwan, Malaysia and New Zealand. Food Quality and Preference, 13(7), 489-495.

Saba, A., Vassallo, M., Shepherd, R., Lampila, P., Arvola, A., \& Dean, M. (2010). Country-wise differences in perception of health-related messages in cereal based food products. Food Quality and Preference, 21(4), 385-393.

Sekaran, U., \& Bougie, R. (2009). Research Methods for business: A skill building approach. $5^{\text {th }}$ ed. United Kingdom: John Wiley and Sons Ltd. Publisher. 448p.

Singer, L., Williams, P. G., Ridges, L., Murray, S., \& McMahon, A. (2006). Consumer reactions to different health claim formats on food labels. Food Australia, 58(3), 92-97.

Sullivan, L. M. (2017). Essentials of Biostatistics in Public Health. United States, US: Jones \& Bartlett Learning. p 89.

Svederberg, E. (2002). Consumers' views regarding health claims on two food packages. Lund: Department of Education, Lund University. 58p. 
Trolle, E., \& Thorsen, A. (2001). Evaluation of health claims from a nutritional perspective. Copenhagen: Nordic Council of Ministers. p 43.

Tudoran, A., Olsen, S. O., \& Dopico, D. C. (2009). The effect of health benefit information on consumers health value, attitudes and intentions. Appetite, 52(3), 568-579.

Urala, N., Arvola, A., \& Lähteenmäki, L. (2003). Strength of health-related claims and their perceived advantage. International Journal of Food Science and Technology, 38(7), 815-826.

Vanasse, T. (2016). How Health Claims on Product Packaging Influence Consumer Perceptions and Purchase Decisions. Retrieved from http://digitalcommons.bryant.edu /cgi/viewcontent.cgi?article=1019andcontext=honor s_marketing, 5 May 2017.

van Kleef, W., van Trijp, H. C. M., \& Luning, P. (2005). Functional foods: Health claim food product compatibility and the impact of health claim framing on consumer evaluation. Appetite, 44(3), 299-308.

van Trijp, H. C. M., \& van der Lans, I. A. (2007). Consumer perceptions of nutrition and health claims. Appetite, 48(3), 305-324.

Verbeke, W. (2005). Consumer acceptance of functional foods: Socio-demographic, cognitive and attitudinal determinants. Food Quality and Preference, 16(1), 45-57.

Verbeke, W., Scholderer, J., \& Lähteenmäki, L. (2009). Consumer appeal of nutrition and health claims in three existing product concepts. Appetite, 52(3), 684692.

Wegner, T. (2010). Applied business statistics: Methods and Excel-based applications. South Africa: Juta and Company Ltd. p 214.

Wills, J. M., Bonsmann, S. S., Kolka, M., \& Grunert, K. G. (2012). European consumers and health claims: attitudes, understanding and purchasing behaviour. Proceedings of the Nutrition Society, 71(2), 229-236.

Williams, P. (2005). Consumer understanding and use of health claims for foods. Nutrition Reviews, 63(7), 256-264.

Williams, P. G., Ridges, L., Batterham, M., Ripper, B., \& Hung, M. C. (2008). Australian consumer attitudes to health claim-food product compatibility for functional foods. Food Policy, 33(6), 640-643.
Wong, C. H. \& Benjamin, N. (2016). Make JB the second biggest city. Retrieved from http://www.thestar.com.my/news/nation/2016/03/23/ make-jb-the-second-biggest-city-joh or-rulerstrategic-location-a-prime-catalyst-forrealisi ng-itsfu/, 17 April 2017.

Zafar, M. Z., Hashim, N. A., \& Halim, Fairol. (2016). Consumer's perception toward health claims for healthy food selection. Journal of Scientific Research and Development, 3(1), 57-67.

Žeželj, I., Milošević, J., Stojanović, Ž., \& Ognjanov, G. (2012). The motivational and informational basis of attitudes toward foods with health claims. Appetite, 59(3), 960-967. 